\title{
Assessment of Potassium Element on Lentil (Lens culinaris Medic) Agronomy and Nutrient Use Efficiency in Calcareous Soils
}

\author{
Md. Abdul Quddus ${ }^{1, *}$, Md. Ashraf Hossain², Habib Mahammad Naser², Babul Anwar, \\ Md. Abdus Sattar ${ }^{4}$, H. E. M. Khairul Mazed ${ }^{5}$ \\ ${ }^{1}$ Soil and Water Management Section, Horticulture Research Centre, Bangladesh Agricultural Research Institute, Gazipur, Bangladesh \\ ${ }^{2}$ Soil Science Division, Bangladesh Agricultural Research Institute, Gazipur, Bangladesh \\ ${ }^{3}$ Regional Agricultural Research Station, Bangladesh Agricultural Research Institute, Jashore, Bangladesh \\ ${ }^{4}$ Farm Division, Bangladesh Agricultural Research Institute, Gazipur, Bangladesh \\ ${ }^{5}$ Olericulture Division, Bangladesh Agricultural Research Institute, Gazipur, Bangladesh
}

\section{Email address:}

quddus06@yahoo.com (Md. A. Quddus), ashrafbdpre@gmail.com (Md. A. Hossain), nasemh2@yahoo.com (H. M. Naser), babul.bari08@yahoo.com (B. Anwar), satter72@gmail.com (Md. A. Sattar), hemkhairulmazed@gmail.com (H. E. M. K. Mazed)

${ }^{*}$ Corresponding author

\section{To cite this article:}

Md. Abdul Quddus, Md. Ashraf Hossain, Habib Mahammad Naser, Babul Anwar, Md. Abdus Sattar, H. E. M. Khairul Mazed. Assessment of Potassium Element on Lentil (Lens culinaris Medic) Agronomy and Nutrient Use Efficiency in Calcareous Soils. Journal of Energy and Natural Resources. Special Issue: Assessment of Potassium Element on Lentil (Lens culinaris Medic) Agronomy and Nutrient Use Efficiency in Calcareous Soils. Vol. 8, No. 3, 2019, pp. 116-126. doi: 10.11648/j.jenr.20190803.13

Received: August 23, 2019; Accepted: October 5, 2019; Published: October 17, 2019

\begin{abstract}
Potassium (K) is considered as key element for plant growth and physiology and improvement of productivity and quality of crops. The potassium (K) reduction from agricultural soils of Indo-Gangetic plain had been observed due to rapidly increasing intensive cropping systems, in combination with imbalanced fertilization. Now, burning issue is needed to better understand the role and dynamic of $\mathrm{K}$ in plants and $\mathrm{K}$-use efficiency of crops. Hence, this study was undertaken during two consecutive years of 2015-16 and 2016-17 to know the effects of different levels of potassium on lentil productivity, nodulation, nutrient uptake and $\mathrm{K}$ use efficiency. The experiment was laid out in randomized complete block design considering five treatments with thrice replicates. The treatments were $\mathrm{T}_{1}$ (K Control), $\mathrm{T}_{2}\left(15 \mathrm{~kg} \mathrm{~K} \mathrm{ha}^{-1}\right), \mathrm{T}_{3}\left(30 \mathrm{~kg} \mathrm{~K} \mathrm{ha}^{-1}\right), \mathrm{T}_{4}\left(45 \mathrm{~kg} \mathrm{~K} \mathrm{ha}^{-1}\right)$ and $\mathrm{T}_{5}\left(60 \mathrm{~kg} \mathrm{~K} \mathrm{ha}^{-1}\right)$ along with the blanket dose of $\mathrm{N}_{18} \mathrm{P}_{20} \mathrm{~S}_{10} \mathrm{Zn}_{2} \mathrm{~B}_{1.5} \mathrm{~kg} \mathrm{ha}^{-1}$ and cowdung $3 \mathrm{t} \mathrm{ha}^{-1}$. Yield and yield attributes of lentil responded significantly to $\mathrm{K}$ fertilizer. The highest mean seed yield $\left(1684 \mathrm{~kg} \mathrm{ha}^{-1}\right)$ and maximum seed yield increase over control (31.9\%) got from $\mathrm{T}_{5}$ treatment followed by $\mathrm{T}_{4}$ treatment. The highest total nutrient ( $, \mathrm{P}, \mathrm{K}, \mathrm{S}, \mathrm{Zn}$ and $\left.\mathrm{B}\right)$ uptake, maximum nodulation and the highest protein content $(29.4 \%)$ in seed was, however, recorded from the plot receiving of $60 \mathrm{~kg} \mathrm{~K} \mathrm{ha}^{-1}$. Apparent K recovery efficiency was recorded higher $(17.8 \%)$ from $\mathrm{T}_{4}$ treatment. Apparent $\mathrm{K}$ recovery efficiency followed the order: $\mathrm{T}_{4}>\mathrm{T}_{5}>\mathrm{T}_{3}>\mathrm{T}_{2}$. From the economic point of view, $\mathrm{T}_{5}$ followed by $\mathrm{T}_{4}$ treatment is viable and sound. The results of the experiment suggest that $60 \mathrm{~kg} \mathrm{~K} \mathrm{ha}^{-1}$ might be applied along with $\mathrm{N}_{18} \mathrm{P}_{20} \mathrm{~S}_{10} \mathrm{Zn}_{2} \mathrm{~B}_{1.5} \mathrm{~kg} \mathrm{ha}^{-1}$ for lentil cultivation in calcareous soils of Bangladesh. The $\mathrm{K}$ rates for fertilizer recommendation in lentil need to be revised to take account for highest yield by higher increasing rate of $\mathrm{K}$ in soil.
\end{abstract}

Keywords: Potassium, Lentil Yield, Nodulation, Nutrient Uptake, Calcareous Soil

\section{Introduction}

Most of the crops during their growth stages experience one or more abiotic stresses such as drought, salinity, metal toxicity, high or chilling temperatures, etc [1]. Potassium plays a key role to mitigate the various abiotic stresses. 
Potassium takes part in protein synthesis, carbohydrate metabolism, and enzyme activation. It assists in the cationanion balance, osmoregulation, water movement, energy transfer, and many other processes [2]. A poor root system, lodging, and yield reductions are common phenomena related to $\mathrm{K}$ deficiency. Lacking of $\mathrm{K}$ fertilizer increases the plants susceptibility to various diseases and pest infestation and makes plants vulnerable to damage under various stress conditions [3]. Most of the soils in different agro-ecological zones of Bangladesh are more or less potassium deficient especially in calcareous soil [4].

Rapid growing population of Bangladesh is required nutritious (protein rich) food. Lentil (Lens culinaris Medic) is one of the protein rich nutritious crops which production needs to be increased by the application of judicious $\mathrm{K}$ level. It is well adapted and can produce reasonable yield on such soils of low mineral status. Lentil is an ancient edible pulse crop [5]. It is a small, light green, herbaceous plant with much branched stem which belongs to the family Fabaceae [6]. Lentil contains about $11 \%$ water, $25 \%$ protein and $60 \%$ carbohydrates. It is also rich in calcium, iron, zinc and niacin [7]. It improves the soil fertility status through biological nitrogen fixation [8]. The average yield of lentil in Bangladesh is low (752 kg ha $\left.{ }^{-1}\right)$ due to non-judicious use of manures and fertilizers especially potassium [9]. Due to protein demand for rapid growing population, lentil production needs to be increased by the application of judicious K level.

Much practical experience in farmers' fields of Bangladesh, however, the $\mathrm{K}$ nutrition of this crop (lentil) is taken inadequate attention in research and management. On the other hand, several studies reported that high yielding variety and intensive cropping may cause heavy depletion of soil K [10-12]. Depletion of soil nutrients, particularly K, is a probable cause of yield decline of pulse (lentil) crop. Limited research work was done the assessment of $\mathrm{K}$ rate on lentil agronomy and nutrient use efficiency in calcareous soils of Bangladesh. Potassium nutrition is associated with the nodulation; grain quality and protein content [13]. It also helps to improve disease resistance, drought stress, tolerance to water stress, winter hardiness, tolerance to plant pests and uptake efficiency of other nutrients [14]. The observed decline in available $\mathrm{K}$, however, highlights the need to revise current $\mathrm{K}$ fertilizer recommendation for sustaining lentil productivity and quality in calcareous soils. Hence, the present study was undertaken to evaluate the K dose for yield attributes, nodulation, quality, and yield maximization of lentil as well as to measure the nutrient use efficiency.

\section{Method}

\subsection{Site Description}

The study area is at the Regional Agricultural Research Station (RARS), Bangladesh Agricultural Research Institute (BARI), Jashore. The area was elevation $6.71 \mathrm{~m}, 23.11^{\circ} \mathrm{N}$ and $89.14^{\circ} \mathrm{E}$ [15]. It belongs to the agroecological zone, High Ganges River Floodplain (AEZ-11). According to general soil classification, it falls under calcareous brown floodplain soils with Gopalpur soil series (Soil taxonomy: orderInceptisols and sub-group-Aquic Eutrochrepts). The experimental site has subtropical humid climatic condition. It is characterized by comparatively high monsoon rainfall, high humidity, and high temperature. Long day with less clear sunshine, sometimes the sky remains cloudy for heavy rainfall during April to September. The scanty rainfall, low humidity and low temperature, short day and more clear sunshine during October to March. The average temperature ranges from 20 to $35^{\circ} \mathrm{C}$ and average annual rainfall varies from 1650 to $2000 \mathrm{~mm}$ across the year. The area got rainfall from 1.7 to $20 \mathrm{~mm}$ at $1^{\text {st }}$ year $(2015-16)$ and 7.9 to $12.2 \mathrm{~mm}$ at $2^{\text {nd }}$ year (2016-17) during October to March. The mean minimum and maximum air temperatures during October to March of the experiment were 10.3 to $30.4^{\circ} \mathrm{C}$ at $1^{\text {st }}$ year and $9.4632 .5^{\circ} \mathrm{C}$ at $2^{\text {nd }}$ year, respectively. The average minimum and maximum humidity (\%) were 71.6 to 88.6 at $1^{\text {st }}$ year and 71.3 to 85.6 at $2^{\text {nd }}$ year, respectively during October to March (Table 1).

Table 1. Weather data during the experimental period at Jashore.

\begin{tabular}{|c|c|c|c|c|c|c|c|c|c|c|}
\hline \multirow{3}{*}{ Months } & \multicolumn{4}{|c|}{ Avg. Temperature $\left({ }^{\circ} \mathrm{C}\right)$} & \multicolumn{4}{|c|}{ Avg. Humidity (\%) } & \multicolumn{2}{|c|}{ Rainfall (mm) } \\
\hline & \multicolumn{2}{|c|}{$2015-16$} & \multicolumn{2}{|c|}{ 2016-17 } & \multicolumn{2}{|c|}{$2015-16$} & \multicolumn{2}{|c|}{ 2016-17 } & \multirow{2}{*}{$\begin{array}{l}2015-16 \\
-\end{array}$} & \multirow{2}{*}{$\begin{array}{l}\text { 2016-17 } \\
-\end{array}$} \\
\hline & Min. & Max. & Min. & Max. & Min. & Max. & Min. & Max. & & \\
\hline November & 18.3 & 26.1 & 15.6 & 25.7 & 71.6 & 86.8 & 73.5 & 82.4 & 0 & 0 \\
\hline December & 17.9 & 20.8 & 12.9 & 22.6 & 74.8 & 84.6 & 71.4 & 81.1 & 0 & 0 \\
\hline January & 10.3 & 23.9 & 9.46 & 26.6 & 73.3 & 83.4 & 71.3 & 80.1 & 1.7 & 0 \\
\hline February & 15.7 & 27.1 & 10.7 & 27.8 & 77.4 & 83.5 & 73.7 & 79.9 & 15 & 0 \\
\hline March & 18.6 & 30.4 & 14.7 & 32.5 & 76.3 & 84.4 & 73.8 & 80.0 & 20 & 7.9 \\
\hline
\end{tabular}

Source: Weather centre, RARS, Jashore, Bangladesh

The soil sample of the experimental area was collected (0-15 $\mathrm{cm}$ depth) with soil auger, before sowing the test crop. Percentage of sand, silt and clay was determined by hydrometer method [16]. The textural class was determined using Marshall's Triangular Coordinates of USDA system. The chemical properties and textural classes are shown in Table 2. 
Table 2. Fertility status of initial soil sample of the experimental field.

\begin{tabular}{|c|c|c|c|c|c|c|c|c|c|c|c|c|c|}
\hline \multirow{2}{*}{ Location } & \multirow{2}{*}{$\mathbf{p H}$} & \multirow{2}{*}{$\begin{array}{l}\text { Previous } \\
\text { crop }\end{array}$} & \multirow{2}{*}{$\begin{array}{l}\text { OM } \\
(\%)\end{array}$} & \multirow{2}{*}{$\begin{array}{l}\text { Total N } \\
(\%)\end{array}$} & $\mathrm{Ca}$ & $\mathbf{K}$ & $\mathbf{P}$ & $\mathbf{S}$ & $\mathbf{Z n}$ & B & \multicolumn{3}{|c|}{ Soil particles (\%) } \\
\hline & & & & & \multicolumn{2}{|c|}{ meq. $100 \mathrm{~g}^{-1}$} & $\mathrm{mg} \mathrm{kg}^{-1}$ & & & & Sand & Silt & Clay \\
\hline Jashore (result) & 8.2 & & 1.63 & 0.071 & 16.4 & 0.14 & 14 & 14.6 & 0.86 & 0.15 & 19.25 & 62.80 & 17.95 \\
\hline Critical level & - & rice & - & 0.12 & 2.0 & 0.12 & 10 & 10 & 0.60 & 0.20 & - & - & - \\
\hline Interpretation* & slightly alkaline & & low & very low & high & low & medium & medium & low & low & Silt loal & & \\
\hline
\end{tabular}

*FRG [26]

\subsection{Land Prepation, Treatments, Design and Layout}

The land was first opened by a tractor operated chisel plough and then prepared thoroughly by ploughing with power tiller followed by laddering and leveling. The land was weed and stubbles free. The trial was arranged with 5 treatments including control. Five levels of $\mathrm{K}(0,15,30,45$ and $\left.60 \mathrm{~kg} \mathrm{ha}^{-1}\right)$ were considered for the treatments such as $\mathrm{T}_{1}$ (K Control), $\mathrm{T}_{2}\left(15 \mathrm{~kg} \mathrm{~K} \mathrm{ha}^{-1}\right), \mathrm{T}_{3}\left(30 \mathrm{~kg} \mathrm{~K} \mathrm{ha}^{-1}\right), \mathrm{T}_{4}(45 \mathrm{~kg} \mathrm{~K}$ $\left.\mathrm{ha}^{-1}\right), \mathrm{T}_{5}\left(60 \mathrm{~kg} \mathrm{~K} \mathrm{ha}^{-1}\right)$ along with the blanket dose of other fertilizers of $\mathrm{N}_{18} \mathrm{P}_{20} \mathrm{~S}_{10} \mathrm{Zn}_{2} \mathrm{~B}_{1.5} \mathrm{~kg} \mathrm{ha}^{-1}$ and cowdung $3 \mathrm{t} \mathrm{ha}^{-1}$. The experiment was laid out in randomized complete block design (RCBD) with thrice replicates having 15 unit plots. The unit plot size was $12 \mathrm{~m}^{2}(4 \mathrm{~m} \times 3 \mathrm{~m})$.

\subsection{Agronomic Practices}

Before plot preparation, cowdung was applied in the experimental field. The unit plot ( $4 \mathrm{~m} \times 3 \mathrm{~m}$ ) was prepared by manually with spade. Every plot received an equal amount of other fertilizers at $\mathrm{N}_{18} \mathrm{P}_{20} \mathrm{~S}_{10} \mathrm{Zn}_{2} \mathrm{~B}_{1.5} \mathrm{~kg} \mathrm{ha}^{-1}$ as urea, TSP, gypsum, zinc sulphate and boric acid. The potassium was applied treatment wise as muriat of potash (MoP). The unit plots were separated from each other by an alley of $50 \mathrm{~cm}$ width. Seeds of lentil (cv. BARI Masur-7) were treated using the fungicide Provex 200 (at $2.5 \mathrm{~g} \mathrm{~kg}^{-1}$ seeds) before sowing to control of root rot disease. Treated seeds were sown (@35 $\left.\mathrm{kg} \mathrm{ha}^{-1}\right)$ continuously in rows (10 rows/plot) maintaining row to row spacing of $30 \mathrm{~cm}$ on 13 November, 2015 and 12 November, 2016. Manually weeding as well as thining of seedlings was done at 25 days after sowing (DAS). Again, hand weeding was done at $50 \mathrm{DAS}$. Three sprays were done with fungicide of Rovral starting from 55 DAS to control Stemphylium blight disease and two times insecticide (Karate (a) $2 \mathrm{ml} \mathrm{L}^{-1}$ of water) sprayed at 10 days interval starting from 60 DAS to overcome insect infestation. The crop was harvested at maturity. Data on seed yield $\left(\mathrm{kg} \mathrm{ha}^{-1}\right)$ at around $10 \%$ moisture basis were recorded from the whole plot technique. For stover yield $\left(\mathrm{kg} \mathrm{ha}^{-1}\right)$, mature plants were collected from two $1 \mathrm{~m}^{2}$ quadrates in each plot at harvest time. The yield contributing characters namely: number of branch per plant, plant height and number of pods plant ${ }^{-1}$ were recorded from ten plants selected randomly from each unit plot. Pods were detached from every plant and the number of pods per plant was counted and averaged. Thousand seed weight $(\mathrm{g})$ was determined by the counting of 500 seeds randomly from each plot and weighing through electronic balance and converting it into 1000 -seed weight. For nodule counting per plant, 5 plants from each plot were selected randomly at seedling, vegetative, flowering and podding stages. Plants were smoothly uprooted and the soil from roots was removed carefully using tap water. Separated nodules were sliced into two pieces to observe the inside color for nodules activity. The light-pink or red coloured nodules were considered as active. Percentage of harvest index (HI) was determined by the formula-

$$
H I=\frac{\text { Economic yield }}{\text { Biological yield }} \times 100
$$

\subsection{Soil and Plant Analysis}

Postharvest soil samples of the experimental plot were collected from $0-15 \mathrm{~cm}$ depth. The combined soil sample of each plot was brought to the laboratory and spread on a brown paper for air drying. The air-dried soil samples were ground and passed through a 2-mm sieve. After sieving, the prepared soil samples were kept into plastic containers with proper label for chemical analysis.

Soil $\mathrm{pH}$ was measured by glass electrode $\mathrm{pH}$ meter using soil: water ratio of 1:2.5 [17]. Organic carbon was determined following the wet oxidation method as described by Page et al. [17] and the organic matter content was calculated by multiplying the \% organic carbon with the Van Bemmelen factor 1.73. Total $\mathrm{N}$ by Microkjeldahl method [18]; available $\mathrm{P}$ was determined following Olsen method as described by Page et al. [17]; exchangeable $\mathrm{K}$ by $1 \mathrm{~N}$ $\mathrm{NH}_{4} \mathrm{OAc}$ method [19]; exchangeable $\mathrm{Ca}$ by $1 \mathrm{~N} \mathrm{NH}_{4} \mathrm{OAc}$ method [20]; available $\mathrm{S}$ by turbidity method using $\mathrm{BaCl}_{2}$ [21]; available $\mathrm{Zn}$ by DTPA method [22]; available $\mathrm{B}$ by azomethine-H method [17].

Ground stover and seed samples were digested with di-acid mixture $\left(\mathrm{HNO}_{3}-\mathrm{HClO}_{4}\right)(5: 1)$ as described by Piper [23] for the determination- concentration of $\mathrm{N}$ (Micro-Kjeldahl method), $\mathrm{P}$ (spectrophotometer method), $\mathrm{K}$ (atomic absorption spectrophotometer method), $\mathrm{S}$ (turbidity method using $\mathrm{BaCl}_{2}$ by spectrophotometer), Zn (atomic absorption spectrophotometer method, VARIAN SpectrAA 55B, Australia) and B (spectrophotometer following azomethine-H method).

\subsection{Protein Content and Nutrient Uptake Determination}

Protein content was measured by estimating the $\mathrm{N}$ content and then multiplying the $\mathrm{N}$ value by 6.25 [24]. Nutrient (N, P, $\mathrm{K}, \mathrm{S}, \mathrm{Zn}$ and B) uptake by the test crop was calculated from the results of crop yield and nutrient content in seed and straw [25].

\subsection{Nutrient Use Efficiency}

Agronomic efficiency (AE) was calculated according to 
equation

$$
A E=\frac{\text { Yield in } \mathrm{kg} \text { with } \mathrm{K} \text { fertilizer-Yield in } \mathrm{kg} \text { with no } \mathrm{K} \text { fertilizer }}{\text { Amount of } \mathrm{K} \text { frtilizer applied in } \mathrm{kg}}
$$

Physiological efficiency (PE) was calculated according to equation

$$
P E=\frac{Y-Y_{0}}{U-U_{0}}
$$

Where, $\mathrm{Y}$ is the economic yield of the potassium fertilized plot, $\mathrm{Y}_{0}$ is the yield of the potassium unfertilized plot, $\mathrm{U}$ is the nutrient uptake by lentil with $\mathrm{K}$ fertilized plot and $\mathrm{U}_{0}$ is the nutrient uptake by lentil with K unfertilized plot [26].

Apparent nutrient recovery efficiency (ANR) was calculated according to the equation below [27]

$$
\mathrm{ANR}=\frac{(\text { Nutrient uptake } \mathrm{F}, \mathrm{kg}-\text { Nutrient uptake C,kg) }}{(\text { Quantity of nutrient applied }, \mathrm{kg})} \times 100
$$

\subsection{Statistical Analysis}

Data of yield attributes, number of nodules per plant, protein content and $\mathrm{N}, \mathrm{P}, \mathrm{K}, \mathrm{S}, \mathrm{Zn}, \mathrm{B}$ uptake were computed on average of two study years. Data of all parameters were statistically analysed by ANOVA procedure. Then, multiple comparisons were done by LSD at 5\% level [28].

\subsection{Partial Budget Analysis}

Benefit cost ratio (BCR) refers the ratio of gross return to the total variable cost of production of any project in monetary terms. Higher BCR expresses higher return from the production and vice-versa. BCR was determined by the below formula [29]

$$
B C R=\frac{G R}{V C}
$$

BCR was counted for a hectare of land. Treatment wise management cost was calculated by adding the cost incurred for labours, ploughing and inputs for each treatment. The seed yield was converted $\mathrm{kg} \mathrm{ha}^{-1}$. This yield was utilized to calculate the gross return. The shadow prices (land rent, stover cost etc) were not considerd. The gross return was measured by multiplying the seed yield by the present unit price of lentil. Net return was calculated by subtracting management cost from gross return.

\section{Results}

\subsection{Growth and Yield Attributes of Lentil}

The number of branches per plant was showed significantly $(\mathrm{P}<0.05)$ difference due to application of potassium rates (Table 3 ). Results reveal that the highest number of primary branches per plant (2.93) was recorded from the treatment $T_{5}$ which was statistically similar with $T_{4}$, $T_{3}$ and $T_{2}$ treatments but significantly different with $T_{1}$ treatment. The lowest number of branches per plant (2.24) was achieved in $\mathrm{K}$ control $\left(\mathrm{T}_{1}\right)$ treatment (Table 3$)$. Different rates of potassium contributed significantly $(\mathrm{P}<0.05)$ to improve the plant height of lentil (Table 3). This study results showed that the highest plant height $(37.0 \mathrm{~cm})$ was obtained in the plot receiving of $60 \mathrm{~kg} \mathrm{~K} \mathrm{ha}{ }^{-1}\left(\mathrm{~T}_{5}\right)$ which was significantly different over the other treatments but statistically identical to the plots receiving of $45 \mathrm{~kg} \mathrm{~K}^{-1}$ $\left(\mathrm{T}_{4}\right)$ and $30 \mathrm{~kg} \mathrm{~K} \mathrm{ha}^{-1}\left(\mathrm{~T}_{3}\right)$. The lowest plant height $(30.7 \mathrm{~cm})$ was obtained from $\mathrm{K}$ control $\left(\mathrm{T}_{1}\right)$ treatment (Table 3 ).

Number of pods per plant is very important yield attribute which significantly correlated to achieve higher seed yield (Figure 1). However, the number of pods per plant affected significantly to different rates of potassium (Table 3 ). The maximum number of pods per plant (85.2) was found in the treatment $T_{5}$ followed by $T_{4}$ treatment and the minimum number of pods per plant (59.7) was observed in $\mathrm{K}$ control $\left(\mathrm{T}_{1}\right)$ treatment (Table 3 ). The seed weight also significantly correlated to reflect the higher yield of lentil (Figure 1). From the study, the thousand seed weight varied from 18.8 to 22.1 $\mathrm{g}$ across the different $\mathrm{K}$ rates. The highest 1000 seed weight $(22.1 \mathrm{~g})$ was obtained from the treatment $\mathrm{T}_{5}$ which was significantly different with the others treatment but it was statistically identical to $T_{4}$ treatment and the lowest 1000 seed weight $(18.8 \mathrm{~g})$ was recorded in $\mathrm{K}$ control treatment (Table 3).

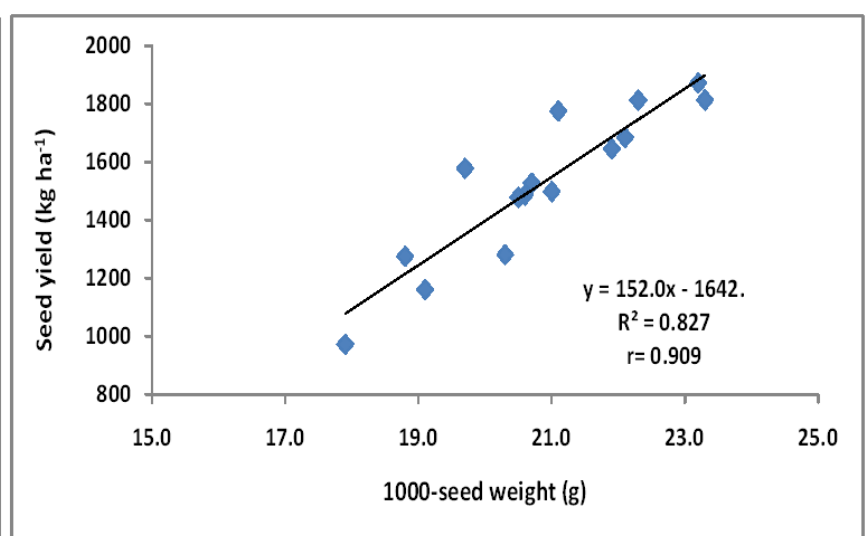

Figure 1. Relationship between seed yield and number of pods per plant \& 1000-seed weight of lentil. 
Table 3. Effect of different levels of potassium on growth and yield attributes of lentil (Pooled data of two years).

\begin{tabular}{|c|c|c|c|c|}
\hline Treatment & No. of branches plant ${ }^{-1}$ & Plant height (cm) & No. of pods plant ${ }^{-1}$ & 1000 seeds wt (g) \\
\hline $\mathrm{T}_{1}$ (K Control) & $2.24 \mathrm{~b}$ & $30.7 \mathrm{c}$ & $59.7 \mathrm{c}$ & $18.8 \mathrm{c}$ \\
\hline $\mathrm{T}_{2}\left(15 \mathrm{~kg} \mathrm{~K} \mathrm{ha}^{-1}\right)$ & $2.45 \mathrm{ab}$ & $34.0 \mathrm{~b}$ & $73.9 \mathrm{~b}$ & $20.6 b$ \\
\hline $\mathrm{T}_{3}\left(30 \mathrm{~kg} \mathrm{~K} \mathrm{ha}^{-1}\right)$ & $2.87 \mathrm{a}$ & $35.1 \mathrm{ab}$ & $74.2 \mathrm{~b}$ & $20.7 b$ \\
\hline $\mathrm{T}_{4}\left(45 \mathrm{~kg} \mathrm{~K} \mathrm{ha}^{-1}\right)$ & $2.88 \mathrm{a}$ & $36.5 \mathrm{ab}$ & $82.6 \mathrm{ab}$ & $21.9 \mathrm{a}$ \\
\hline $\mathrm{T}_{5}\left(60 \mathrm{~kg} \mathrm{~K} \mathrm{ha}^{-1}\right)$ & $2.93 \mathrm{a}$ & $37.0 \mathrm{a}$ & $85.2 \mathrm{a}$ & $22.1 \mathrm{a}$ \\
\hline CV $(\%)$ & 10.3 & 4.16 & 5.97 & 2.24 \\
\hline $\operatorname{LSD}(0.05)$ & 0.52 & 2.72 & 8.43 & 0.88 \\
\hline
\end{tabular}

Values within the same column with a common letter do not differ significantly $(\mathrm{P}<0.05)$

\subsection{Yields of Lentil}

The seed yield of lentil responded significantly to the application of different level of potassium (Table 4). The experimental results reveal that the highest seed yield (1701 $\mathrm{kg} \mathrm{ha}^{-1}$ ) in $1^{\text {st }}$ year was recorded from $\mathrm{T}_{5}$ treatment which was significantly different with the other treatments but it was statistically similar to $T_{4}$ treatment. Smilarly in $2^{\text {nd }}$ year, the highest seed yield $\left(1667 \mathrm{~kg} \mathrm{ha}^{-1}\right)$ was found in $\mathrm{T}_{5}$ treatment which was significantly different with the other treatments but it was statistically identical with $\mathrm{T}_{4}$ and $\mathrm{T}_{3}$ treatments. The lowest seed yield (1199 $\mathrm{kg} \mathrm{ha}^{-1}$ in $1^{\text {st }}$ year and $1352 \mathrm{~kg}$ $\mathrm{ha}^{-1}$ in $2^{\text {nd }}$ year) was recorded from $\mathrm{K}$ control treatment
(Table 4). Regarding straw yield of lentil, it was showed similar trend of seed yield. The percent seed yield increase over control varied from 16.5 to $31.9 \%$ (Table 4 ). The highest seed yield increase (31.9\%) over control was calculated from $\mathrm{T}_{5}$ followed by $\mathrm{T}_{4}$ treatments and the lowest seed yield increase (16.5\%) was found in $T_{2}$ treatment. In the present experiment, harvest index (HI) of lentil was ranged across $\mathrm{K}$ rates from $37.1 \%$ to 38.7 where the highest $\mathrm{HI}$ $(38.7 \%)$ was recorded from $\mathrm{T}_{3}$ treatment which was statistically similar to $\mathrm{T}_{4}$ and $\mathrm{T}_{5}$ treatment. The lowest $\mathrm{HI}$ (37.1\%) was found in $\mathrm{K}$ control $\left(\mathrm{T}_{1}\right)$ treatment (Table 4).

Table 4. Effect of different levels of potassium on seed and stover yields \& harvest index of lentil.

\begin{tabular}{|c|c|c|c|c|c|c|c|c|}
\hline \multirow{2}{*}{ Treatment } & \multicolumn{3}{|c|}{ Seeds yield $\left(\mathrm{kg} \mathrm{ha}^{-1}\right)$} & \multirow{2}{*}{$\begin{array}{l}\text { \%yield increase } \\
\text { over control }\end{array}$} & \multicolumn{3}{|c|}{ Straw yield $\left(\mathrm{kg} \mathrm{ha}^{-1}\right)$} & \multirow{2}{*}{ HI (\%) } \\
\hline & $\mathbf{1}^{\text {st }} \mathrm{Yr}$. & $2^{\text {nd }} Y r$. & mean & & $1^{\text {st }} Y r$. & $2^{\text {nd }} Y r$. & mean & \\
\hline $\mathrm{T}_{1}$ (K Control) & $1199 \mathrm{c}$ & $1352 \mathrm{c}$ & 1276 & - & $1999 \mathrm{c}$ & $2314 b$ & 2157 & $37.1 \mathrm{~b}$ \\
\hline $\mathrm{T}_{2}\left(15 \mathrm{~kg} \mathrm{~K} \mathrm{ha}^{-1}\right)$ & $1493 b$ & $1480 \mathrm{~b}$ & 1487 & 16.5 & $2317 b$ & $2447 b$ & 2382 & $38.2 \mathrm{ab}$ \\
\hline $\mathrm{T}_{3}\left(30 \mathrm{~kg} \mathrm{~K} \mathrm{ha}^{-1}\right)$ & $1494 b$ & $1562 \mathrm{ab}$ & 1528 & 19.7 & $2335 b$ & $2484 b$ & 2410 & $38.7 \mathrm{a}$ \\
\hline $\mathrm{T}_{4}\left(45 \mathrm{~kg} \mathrm{~K} \mathrm{ha}^{-1}\right)$ & $1642 \mathrm{ab}$ & $1648 \mathrm{a}$ & 1645 & 28.9 & $2629 a$ & $2668 \mathrm{a}$ & 2649 & $38.3 \mathrm{ab}$ \\
\hline $\mathrm{T}_{5}\left(60 \mathrm{~kg} \mathrm{~K} \mathrm{ha}^{-1}\right)$ & $1701 \mathrm{a}$ & $1667 \mathrm{a}$ & 1684 & 31.9 & $2737 \mathrm{a}$ & $2718 \mathrm{a}$ & 2728 & $38.2 \mathrm{ab}$ \\
\hline CV $(\%)$ & 5.35 & 3.85 & - & - & 2.59 & 3.68 & - & 2.08 \\
\hline
\end{tabular}

Values within the same column with a common letter do not differ significantly $(\mathrm{P}<0.05)$

A linear positive relationship was observed in potassium application. The trend of seed yield increased significantly positive between the applications of 45 to $60 \mathrm{~kg} \mathrm{~K} \mathrm{ha}^{-1}$. Therefore, optimization doses of $\mathrm{K}$ fertilizer will be estimated after rearranging the $\mathrm{K}$ levels in future study (Figure 2).

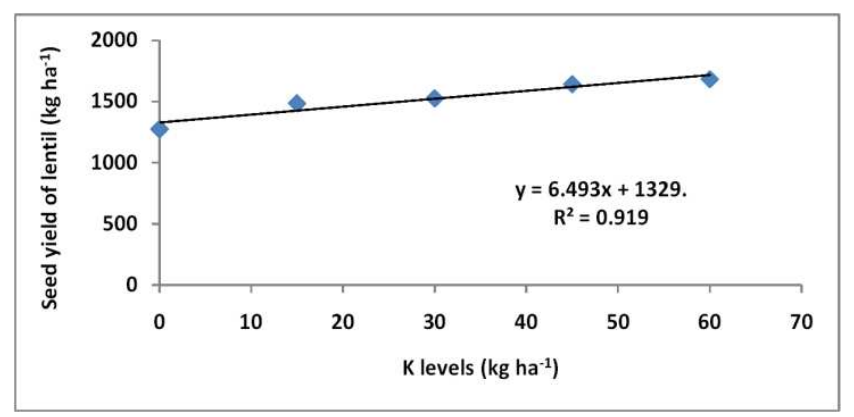

Figure 2. Relationship between K application and seed yield of lentil.

\subsection{Number of Nodules Per Plant and Protein Content in Seed of Lentil}

The results of the Table 5 has showed that the number of nodules per plant was gradually increased from 32 days after sowing (DAS) to $62 \mathrm{DAS}$, and then it was decreased. Number of nodules per plant was influenced significantly due to application of different levels of potassium. In 32 days after sowing, the numbers of nodules per plant varied from 7.37 to 10.0 , in $47 \mathrm{DAS}$, it was ranged from 40.3 to 50.4 , in 62 DAS, it was from 45.4 to 57.2 and in 77 DAS, this range varied from 20.6 to 28.8 (Table 5). The highest number of nodules per plant was recorded from the treatment $T_{5}$ in all the nodule collection dates followed by $\mathrm{T}_{4}$ and $\mathrm{T}_{3}$ treatments. The lowest nodule values were obtained from the $\mathrm{K}$ control treatment (Table 5). The experimental results demonstrate that the highest nodules formation were occured during early to mid flowering. After flowering, nodule efficiency was reduced and began to shut down. In the present study, the protein content in seed of lentil was affected significantly by the application of different levels of $\mathrm{K}$ (Table 5). The highest protein content $(29.4 \%)$ was found in the treatment $T_{5}$ that was statistically similar to $\mathrm{T}_{4}$ and $\mathrm{T}_{3}$ treatment. The significantly lowest protein content $(26.1 \%)$ was obtained without $\mathrm{K}$ fertilizer application (Table 5). 
Table 5. Effect of different rates of potassium on number of nodule per plant in different dates and protein content of lentil (Pooled data of two years).

\begin{tabular}{lllll}
\hline Treatment & $\begin{array}{l}\text { No. of nodules in } \\
\text { 32 DAS }\end{array}$ & $\begin{array}{l}\text { No. of nodules in } \\
\text { 47 DAS }\end{array}$ & $\begin{array}{l}\text { No. of nodules in } \\
\text { 62 DAS }\end{array}$ & $\begin{array}{l}\text { No. of nodules in } \\
\text { 77 DAS }\end{array}$ \\
\hline $\mathrm{T}_{1}(\mathrm{~K} \mathrm{Control})$ & $7.37 \mathrm{~d}$ & $40.3 \mathrm{~b}$ & $45.4 \mathrm{~b}$ & $20.6 \mathrm{~b}$ \\
$\mathrm{~T}_{2}\left(15 \mathrm{~kg} \mathrm{~K} \mathrm{ha}^{-1}\right)$ & $8.40 \mathrm{c}$ & $45.4 \mathrm{ab}$ & $48.8 \mathrm{ab}$ & $24.2 \mathrm{ab}$ \\
$\mathrm{T}_{3}\left(30 \mathrm{~kg} \mathrm{~K} \mathrm{ha}^{-1}\right)$ & $8.43 \mathrm{c}$ & $46.6 \mathrm{a}$ & $50.6 \mathrm{ab}$ & $26.1 \mathrm{c}$ \\
$\mathrm{T}_{4}\left(45 \mathrm{~kg} \mathrm{~K} \mathrm{ha}^{-1}\right)$ & $9.00 \mathrm{ab}$ & $47.5 \mathrm{a}$ & $52.4 \mathrm{ab}$ & $27.7 \mathrm{~b}$ \\
$\mathrm{~T}_{5}\left(60 \mathrm{~kg} \mathrm{~K} \mathrm{ha}^{-1}\right)$ & $10.0 \mathrm{a}$ & $50.4 \mathrm{a}$ & $57.2 \mathrm{a}$ & $26.0 \mathrm{ab}$ \\
$\mathrm{CV}(\%)$ & 12.5 & 7.13 & 10.4 & $28.9 \mathrm{ab}$ \\
$\mathrm{LSD}(0.05)$ & 2.04 & 6.18 & 10.0 & $28.8 \mathrm{ab}$ \\
\hline
\end{tabular}

Values within the same column with a common letter do not differ significantly $(\mathrm{P}<0.05)$

\subsection{Nutrient Uptake by Lentil}

Different levels of potassium employed significantly to uptake the N, P, K, S, Zn, and B by lentil (seed and straw) (Tables 6). In the present study, the highest $\mathrm{N}$ uptake by lentil (78.6 $\mathrm{kg} \mathrm{ha}^{-1}$ by seed and $44.6 \mathrm{~kg} \mathrm{ha}^{-1}$ by straw) was found in $\mathrm{T}_{5}$ treatment, which was significanly different over the other treatments but it was statistically similar to $\mathrm{T}_{4}$ treatment. The lowest $\mathrm{N}$ uptake $\left(53.2 \mathrm{~kg} \mathrm{ha}^{-1}\right.$ by seed and $33.4 \mathrm{~kg} \mathrm{ha}^{-1}$ by straw) was noted from the $\mathrm{K}$ control $\left(\mathrm{T}_{1}\right)$ treatment (Table 6). The total $\mathrm{N}$ uptake by lentil was significantly increased due to increasing the rate of $\mathrm{K}$ application. The total $\mathrm{N}$ uptake by lentil varied from 86.6 to $123 \mathrm{~kg} \mathrm{ha}^{-1}$ across the treatments (Figure 3). In this experiment, the highest $\mathrm{P}$ uptake by lentil seed $\left(7.20 \mathrm{~kg} \mathrm{ha}^{-1}\right)$ and straw $\left(5.35 \mathrm{~kg} \mathrm{~h}^{-1}\right)$ was observed in $\mathrm{T}_{4}$ treatment followed by $\mathrm{T}_{5}$ treatment and the lowest $\mathrm{P}$ uptake ( $4.22 \mathrm{~kg} \mathrm{ha}^{-1}$ by seed and $3.02 \mathrm{~kg} \mathrm{ha}^{-1}$ by straw) was found in $\mathrm{K}$ control treatment (Table 6). The total P uptake by lentil was ranged from 7.24 to $12.4 \mathrm{~kg} \mathrm{ha}^{-1}$ across the different rates of $\mathrm{K}$ (Figure 3). Incase of $\mathrm{K}$ uptake, the maximum $\mathrm{K}$ uptake by lentil seed $\left(11.1 \mathrm{~kg} \mathrm{ha}^{-1}\right)$ was recorded from the $T_{5}$ treatment, which was significantly different with other treatments but statistically at par $\mathrm{T}_{4}$ treatment. The highest $\mathrm{K}$ uptake by lentil straw $\left(21.2 \mathrm{~kg} \mathrm{ha}^{-1}\right)$ was obtained from the $T_{4}$ treatment, which was significantly different with other treatments but statistically similar to $\mathrm{T}_{5}$ treatment. The lowest $\mathrm{K}$ uptake $\left(7.78 \mathrm{~kg} \mathrm{ha}^{-1}\right.$ by seed and $15.1 \mathrm{~kg} \mathrm{ha}^{-1}$ by straw) was observed in $\mathrm{K}$ control $\left(\mathrm{T}_{1}\right)$ treatment (Table 6). Across the treatment the total $\mathrm{K}$ uptake by lentil varied from
22.9 to $32.2 \mathrm{~kg} \mathrm{ha}^{-1}$ where the highest total $\mathrm{K}$ uptake $(32.2 \mathrm{~kg}$ $\mathrm{ha}^{-1}$ ) was noted in $\mathrm{T}_{5}$ treatment (Figure 3). Regarding $\mathrm{S}$ uptake, the highest $\mathrm{S}$ uptake by lentil $\left(5.30 \mathrm{~kg} \mathrm{ha}^{-1}\right.$ by seed and $13.6 \mathrm{~kg} \mathrm{ha}^{-1}$ by straw) was found in $\mathrm{T}_{4}$ treatment which was shown significantly different over other treatments but statistically identical with $T_{5}$ treatment. The lowest $S$ uptake ( $3.19 \mathrm{~kg} \mathrm{ha}^{-1}$ by seed and $7.98 \mathrm{~kg} \mathrm{ha}^{-1}$ by straw) was observed in $\mathrm{K}$ control $\left(\mathrm{T}_{1}\right)$ treatment (Table 6). The total $\mathrm{S}$ uptake by lentil across the treatments varied from 11.2 to $18.9 \mathrm{~kg} \mathrm{ha}^{-1}$ however, the highest total $\mathrm{S}$ uptake $\left(18.9 \mathrm{~kg} \mathrm{ha}^{-1}\right)$ was obtained from $\mathrm{T}_{4}$ treatment (Figure 3). In this trial, the highest $\mathrm{Zn}$ uptake by lentil seed $\left(0.119 \mathrm{~kg} \mathrm{ha}^{-1}\right.$ by seed and $0.119 \mathrm{~kg} \mathrm{ha}^{-1}$ by straw) was obtained from $\mathrm{T}_{5}$ treatment which was showed statistically alike to $T_{4}$ and $T_{3}$ treatment for seed and alike to $T_{4}$ for stover. The lowest $\mathrm{Zn}$ uptake by the seed and straw of lentil was however, obtained from the $\mathrm{K}$ control $\left(\mathrm{T}_{1}\right)$ treatment (Table 6). The total $\mathrm{Zn}$ uptake by lentil ranged from 0.173 to $0.238 \mathrm{~kg} \mathrm{ha}^{-1}$ across the treatments (Figure 3 ). The highest B uptake by lentil seed $\left(0.066 \mathrm{~kg} \mathrm{ha}^{-1}\right)$ was calculated from the $\mathrm{T}_{5}$ treatment, which was statistically similar to $\mathrm{T}_{4}$ treatment while the maximum B uptake by lentil straw $\left(0.070 \mathrm{~kg} \mathrm{ha}^{-1}\right)$ was noted from $\mathrm{T}_{4}$ treatment, which was statistically similar to $\mathrm{T}_{5}$ treatment. The lowest B uptake by lentil (both seed and straw) was assessed from $\mathrm{K}$ control $\left(\mathrm{T}_{1}\right)$ treatment (Table 6). The total B uptake by test crop varied from 0.097 to $0.135 \mathrm{~kg} \mathrm{ha}^{-1}$ across the treatments (Figure 3).

Table 6. Influence of of potassium on nutrient uptake by lentil seed and straw (pooled data of two years).

\begin{tabular}{|c|c|c|c|c|c|c|}
\hline Treatment & $N\left(\mathrm{~kg} \mathrm{ha}^{-1}\right)$ & $P\left(\mathrm{~kg} \mathrm{ha}^{-1}\right)$ & $K\left(\mathrm{~kg} \mathrm{ha}^{-1}\right)$ & $\mathrm{S}\left(\mathrm{kg} \mathrm{ha}^{-1}\right)$ & $\mathrm{Zn}\left(\mathrm{kg} \mathrm{ha}^{-1}\right)$ & B $\left(\mathrm{kg} \mathrm{ha}^{-1}\right)$ \\
\hline \multicolumn{7}{|l|}{ Lentil seed } \\
\hline $\mathrm{T}_{1}$ (K Control) & $53.2 \mathrm{~d}$ & $4.22 \mathrm{c}$ & $7.78 \mathrm{~d}$ & $3.19 \mathrm{c}$ & $0.084 \mathrm{c}$ & $0.046 \mathrm{c}$ \\
\hline $\mathrm{T}_{2}\left(15 \mathrm{~kg} \mathrm{Kha}^{-1}\right)$ & $66.0 \mathrm{c}$ & $5.35 \mathrm{~b}$ & $9.37 \mathrm{c}$ & $4.02 \mathrm{~b}$ & $0.100 \mathrm{~b}$ & $0.056 \mathrm{~b}$ \\
\hline $\mathrm{T}_{3}\left(30 \mathrm{~kg} \mathrm{~K} \mathrm{ha}^{-1}\right)$ & $71.0 \mathrm{~b}$ & $5.81 \mathrm{~b}$ & $9.93 b c$ & $4.28 \mathrm{~b}$ & $0.110 \mathrm{ab}$ & $0.058 \mathrm{~b}$ \\
\hline $\mathrm{T}_{4}\left(45 \mathrm{~kg} \mathrm{Kha}^{-1}\right)$ & $76.9 \mathrm{a}$ & $6.95 \mathrm{a}$ & $10.6 \mathrm{ab}$ & $5.30 \mathrm{a}$ & $0.117 \mathrm{a}$ & $0.065 \mathrm{a}$ \\
\hline $\mathrm{T}_{5}\left(60 \mathrm{~kg} \mathrm{Kha}^{-1}\right)$ & $78.6 \mathrm{a}$ & $7.20 \mathrm{a}$ & $11.1 \mathrm{a}$ & $5.19 \mathrm{a}$ & $0.119 \mathrm{a}$ & $0.066 \mathrm{a}$ \\
\hline CV $(\%)$ & 2.49 & 7.16 & 3.77 & 7.81 & 6.31 & 6.26 \\
\hline $\operatorname{LSD}(0.05)$ & 3.22 & 0.80 & 0.69 & 0.65 & 0.013 & 0.006 \\
\hline \multicolumn{7}{|l|}{ Lentil straw } \\
\hline $\mathrm{T}_{1}$ (K Control) & $33.4 \mathrm{c}$ & $3.02 \mathrm{c}$ & $15.1 \mathrm{c}$ & $7.98 \mathrm{~d}$ & $0.089 \mathrm{~d}$ & $0.051 \mathrm{~d}$ \\
\hline $\mathrm{T}_{2}\left(15 \mathrm{~kg} \mathrm{~K} \mathrm{ha}^{-1}\right)$ & $37.8 \mathrm{~b}$ & $4.05 \mathrm{~b}$ & $17.4 \mathrm{~b}$ & $10.0 \mathrm{c}$ & $0.100 \mathrm{c}$ & $0.057 \mathrm{~cd}$ \\
\hline $\mathrm{T}_{3}\left(30 \mathrm{~kg} \mathrm{~K} \mathrm{ha}^{-1}\right)$ & $39.3 b$ & $4.34 \mathrm{~b}$ & $18.0 \mathrm{~b}$ & $10.8 \mathrm{~b}$ & $0.110 \mathrm{~b}$ & $0.062 b c$ \\
\hline $\mathrm{T}_{4}\left(45 \mathrm{~kg} \mathrm{~K} \mathrm{ha}^{-1}\right)$ & $44.6 \mathrm{a}$ & $5.35 \mathrm{a}$ & $21.2 \mathrm{a}$ & $13.6 \mathrm{a}$ & $0.118 \mathrm{a}$ & $0.070 \mathrm{a}$ \\
\hline $\mathrm{T}_{5}\left(60 \mathrm{~kg} \mathrm{~K} \mathrm{ha}^{-1}\right)$ & $44.8 \mathrm{a}$ & $5.14 \mathrm{a}$ & $21.1 \mathrm{a}$ & $13.5 \mathrm{a}$ & $0.119 \mathrm{a}$ & $0.069 \mathrm{ab}$ \\
\hline CV (\%) & 2.11 & 8.78 & 5.65 & 2.04 & 2.02 & 6.16 \\
\hline $\operatorname{LSD}(0.05)$ & 1.59 & 0.72 & 1.97 & 0.43 & 0.004 & 0.007 \\
\hline
\end{tabular}

Values within the same column with a common letter do not differ significantly $(\mathrm{P}<0.05)$ 


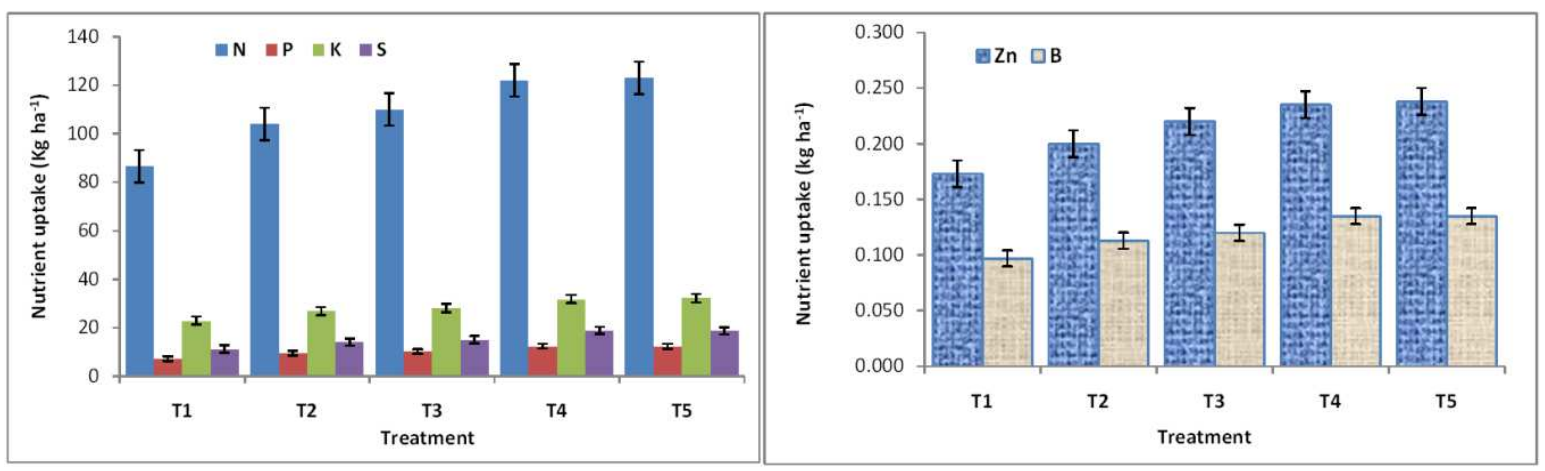

Figure 3. Effect of different rates of potassium on nutrient uptake by lentil (seed+straw) (Mean data of two years).

Error bars represent the SEM

Note: $\mathrm{T}_{1}\left(\mathrm{~K}\right.$ Control), $\mathrm{T}_{2}\left(15 \mathrm{~K} \mathrm{~kg} \mathrm{ha}^{-1}\right), \mathrm{T}_{3}\left(30 \mathrm{~K} \mathrm{~kg} \mathrm{ha}^{-1}\right), \mathrm{T}_{4}\left(45 \mathrm{~kg} \mathrm{~K} \mathrm{ha}^{-1}\right), \mathrm{T}_{5}\left(60 \mathrm{~kg} \mathrm{~K} \mathrm{ha}^{-1}\right)$

\subsection{Nutrient Use Efficiency}

There was a significant influence of $\mathrm{K}$ application on agronomic efficiency (AE) of $\mathrm{K}$ in lentil. Among the treatments, $\mathrm{AE}$ of $\mathrm{K}$ varied over control from 6.30 to $7.58 \mathrm{~kg}$ $\mathrm{kg}^{-1}$. The highest AE of $\mathrm{K}\left(7.58 \mathrm{~kg} \mathrm{~kg}^{-1}\right)$ was found in $\mathrm{T}_{4}$ followed by $\mathrm{T}_{2}$ treatment and the lowest $\mathrm{AE}$ of $\mathrm{K}$ in test crop $\left(6.30 \mathrm{~kg} \mathrm{~kg}^{-1}\right)$ was obtained from $\mathrm{T}_{3}$ and the $2^{\text {nd }}$ lowest was in $\mathrm{T}_{5}$ treatment (Figure 4). In this study, physiological efficiency of $\mathrm{K}$ in lentil was significantly influenced by different levels of $\mathrm{K}$. The $\mathrm{PE}$ of $\mathrm{K}$ over control ranged from 42.5 to $54.1 \mathrm{~kg} \mathrm{~kg}^{-1}$ while the highest PE of K $\left(54.1 \mathrm{~kg} \mathrm{~kg}^{-1}\right)$ was recorded from $T_{2}$ followed by $T_{3}, T_{5}$ and $T_{4}$ treatments and the lowest $\left(42.5 \mathrm{~kg} \mathrm{~kg}^{-1}\right)$ was found in $\mathrm{T}_{4}$ treatment (Figure 4). The PE of $\mathrm{K}$ in lentil decreased gradually with increase of $\mathrm{K}$ rates upto $45 \mathrm{~kg} \mathrm{ha}^{-1}$. Apparent $\mathrm{K}$ recovery efficiency in lentil was significantly affected by different levels of $\mathrm{K}$ application. Application of $45 \mathrm{~kg} \mathrm{~K} \mathrm{ha}^{-1}\left(\mathrm{~T}_{4}\right)$ showed significantly highest apparent potassium recovery $(17.8 \%)$ followed by application of $60 \mathrm{~kg} \mathrm{~K} \mathrm{ha}^{-1}\left(\mathrm{~T}_{5}\right), 30 \mathrm{~kg}$ $\mathrm{K} \mathrm{ha}^{-1}\left(\mathrm{~T}_{3}\right)$ and $15 \mathrm{~kg} \mathrm{~K} \mathrm{ha}^{-1}\left(\mathrm{~T}_{2}\right)$, where the lowest apparent $\mathrm{K}$ recovery efficiency $(13.0 \%)$ was found in the plot receiving of $15 \mathrm{~kg} \mathrm{~K} \mathrm{ha}^{-1}\left(\mathrm{~T}_{2}\right)$ (Figure 5).
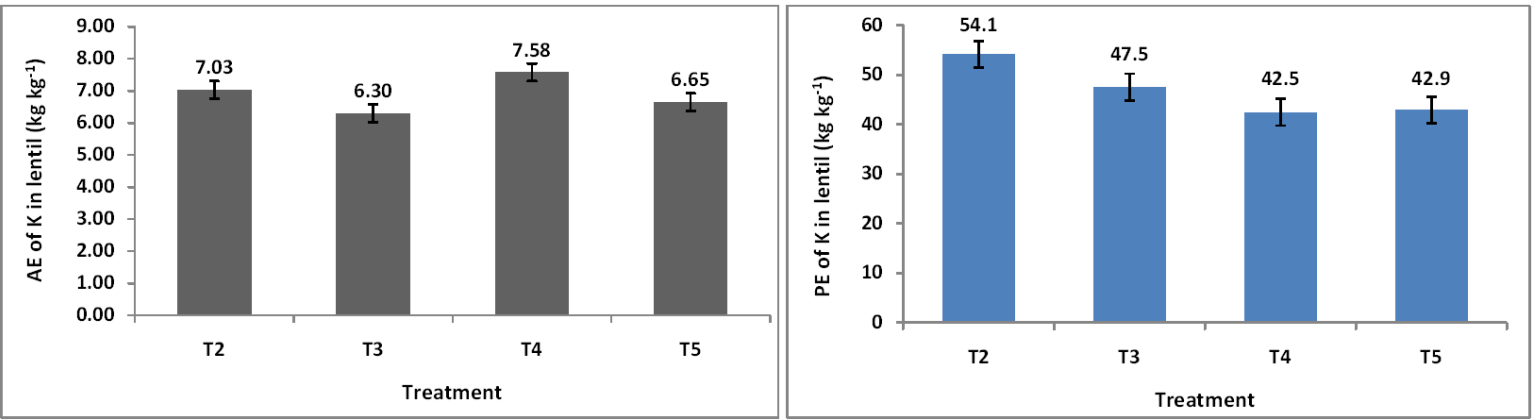

Figure 4. Effect of different rates of potassium on agronomic efficiency (AE) and physiological efficiency (PE) of $K$ in lentil.

Error bars represent the SEM,

Note: $\mathrm{T}_{1}\left(\mathrm{~K}\right.$ Control), $\mathrm{T}_{2}\left(15 \mathrm{~K} \mathrm{~kg} \mathrm{ha}^{-1}\right), \mathrm{T}_{3}\left(30 \mathrm{~K} \mathrm{~kg} \mathrm{ha}^{-1}\right), \mathrm{T}_{4}\left(45 \mathrm{~kg} \mathrm{~K} \mathrm{ha}^{-1}\right), \mathrm{T}_{5}\left(60 \mathrm{~kg} \mathrm{~K} \mathrm{ha}^{-1}\right)$

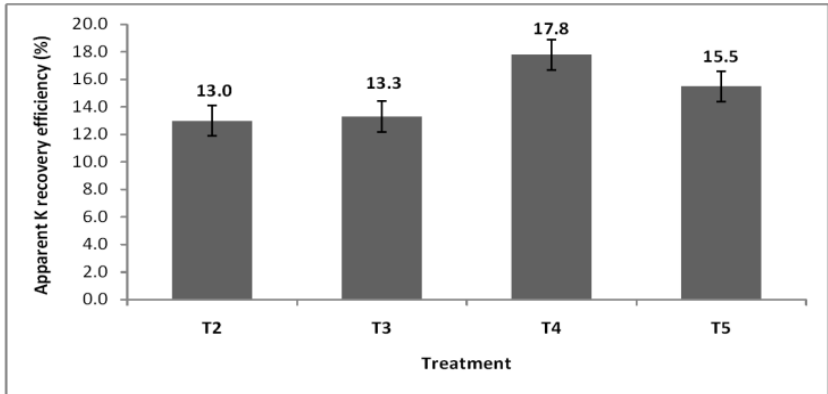

Figure 5. Effect of different rates of potassium on apparent $K$ recovery efficiency in lentil.

Error bars represent the SEM,

Note: $\mathrm{T}_{1}$ (K Control), $\mathrm{T}_{2}\left(15 \mathrm{~K} \mathrm{~kg} \mathrm{ha}^{-1}\right), \mathrm{T}_{3}\left(30 \mathrm{~K} \mathrm{~kg} \mathrm{ha}^{-1}\right), \mathrm{T}_{4}\left(45 \mathrm{~kg} \mathrm{~K} \mathrm{ha}^{-1}\right)$, $\mathrm{T}_{5}\left(60 \mathrm{~kg} \mathrm{~K} \mathrm{ha}^{-1}\right)$

\subsection{Effect of K on Postharvest Soil Properties}

Postharvest soil properties were affected positively by the application of different levels of potassium. In this trial, the $\mathrm{pH}$ of postharvest soils decreased slightly as compared with the initial value, however the changed showed significantly different across the $\mathrm{K}$ treatments (Table 7). Different rates of $\mathrm{K}$ tended to maintain the initial fertility or increased slightly of soil organic matter, N, P, K, S, Zn and B. The amount of organic matter (OM) depending on the $\mathrm{K}$ rates varied from 1.64 to $1.66 \%$, while the highest amount of OM (1.66\%) obtained from $\mathrm{T}_{5}$ followed by $\mathrm{T}_{3}, \mathrm{~T}_{4}$ and $\mathrm{T}_{2}$ treatment and the lowest amount (1.64\%) was found in $\mathrm{K}$ control $\left(\mathrm{T}_{1}\right)$ treatment (Table 7). In most of the cases, the highest $\mathrm{N}, \mathrm{P}, \mathrm{S}, \mathrm{Zn}$ and $\mathrm{B}$ content in postharvest soil was recorded from the $T_{5}$ followed by $T_{4}$ 
treatment, but the $\mathrm{S}$ content was found maximum in $\mathrm{T}_{4}$ followed by $\mathrm{T}_{5}$ treatment and the lowest was from $\mathrm{T}_{1}$ treatment (Table 7 ).

Table 7. Effect of different levels of potassium on postharvest soil $\mathrm{pH}$ and the status of different nutrients at Jashore (mean of two years) with reference to initial soil.

\begin{tabular}{|c|c|c|c|c|c|c|c|c|c|}
\hline \multirow{2}{*}{ Treatment } & \multirow{2}{*}{ pH } & \multirow{2}{*}{ OM (\%) } & \multirow{2}{*}{$\begin{array}{l}\text { Total N } \\
(\%)\end{array}$} & \multirow{2}{*}{\multicolumn{2}{|c|}{$\begin{array}{l}\text { Ca } \\
\text { meq. } 100 \mathrm{~g}^{-1}\end{array}$}} & $\mathbf{P}$ & $\mathbf{S}$ & $\mathbf{Z n}$ & B \\
\hline & & & & & & \multicolumn{4}{|l|}{$\mathrm{mg} \mathrm{kg}^{-1}$} \\
\hline \multicolumn{10}{|l|}{ Jessore } \\
\hline Initial & 8.2 & 1.63 & 0.071 & 16.4 & 0.14 & 14.0 & 14.6 & 0.86 & 0.15 \\
\hline $\mathrm{T}_{1}$ (K Control) & $8.1 \mathrm{a}$ & $1.64 \mathrm{~b}$ & $0.072 \mathrm{c}$ & $15.5 \mathrm{~b}$ & $0.13 \mathrm{e}$ & $13.8 \mathrm{~b}$ & $14.6 \mathrm{e}$ & $0.80 \mathrm{c}$ & $0.15 \mathrm{c}$ \\
\hline $\mathrm{T}_{2}\left(15 \mathrm{~kg} \mathrm{Kh}^{-1}\right)$ & $8.0 \mathrm{ab}$ & $1.65 \mathrm{ab}$ & $0.074 \mathrm{~b}$ & $15.8 \mathrm{a}$ & $0.15 \mathrm{~d}$ & $14.0 \mathrm{~b}$ & $15.0 \mathrm{~d}$ & $0.92 \mathrm{~b}$ & $0.16 \mathrm{bc}$ \\
\hline$T_{3}\left(30 \mathrm{~kg} \mathrm{~K} \mathrm{ha}^{-1}\right)$ & $7.9 \mathrm{bc}$ & $1.66 \mathrm{a}$ & $0.075 \mathrm{ab}$ & $15.6 \mathrm{~b}$ & $0.16 \mathrm{c}$ & $14.6 \mathrm{a}$ & $15.4 \mathrm{c}$ & $0.93 \mathrm{ab}$ & $0.17 \mathrm{ab}$ \\
\hline $\mathrm{T}_{4}\left(45 \mathrm{~kg} \mathrm{Kha}^{-1}\right)$ & $7.9 \mathrm{bc}$ & $1.65 \mathrm{ab}$ & $0.075 \mathrm{ab}$ & $15.2 \mathrm{c}$ & $0.17 \mathrm{~b}$ & $14.5 \mathrm{a}$ & $15.9 \mathrm{a}$ & $0.94 \mathrm{a}$ & $0.17 \mathrm{ab}$ \\
\hline $\mathrm{T}_{5}\left(60 \mathrm{~kg} \mathrm{Kha}^{-1}\right)$ & $7.8 \mathrm{c}$ & $1.66 \mathrm{a}$ & $0.076 \mathrm{a}$ & $15.6 \mathrm{~b}$ & $0.18 \mathrm{a}$ & $14.6 \mathrm{a}$ & $15.6 \mathrm{~b}$ & $0.94 \mathrm{a}$ & $0.18 \mathrm{a}$ \\
\hline
\end{tabular}

Values within the same column with a common letter do not differ significantly $(\mathrm{P}<0.05)$

\subsection{Economic Analysis}

Regarding the cost and return analysis, the maximum gross return TK. $117880 \mathrm{ha}^{-1}$ was calculated from $\mathrm{T}_{5}$ followed by $\mathrm{T}_{4}$. The minimum gross return TK. $89110 \mathrm{ha}^{-1}$ was found in K control treatment. Similarly, the highest net return TK.
$80657 \mathrm{ha}^{-1}$ also recorded from $\mathrm{T}_{5}$ treatment. The highest benefit cost ratio (BCR) 3.17 was counted from $T_{5}$ followed by $\mathrm{T}_{4}$ treatment and the lowest $\mathrm{BCR}$ (2.51) was from $\mathrm{K}$ control treatment (Table 8).

Table 8. Effect different levels of potassium on partial economic of lentil (Pooled data of two years).

\begin{tabular}{|c|c|c|c|c|c|}
\hline Treatment & Seed yield $\left(\mathrm{kg} \mathrm{ha}^{-1}\right)$ & Gross return (Tk. ha ${ }^{-1}$ ) & Cultivation cost $\left(\mathrm{Tk} . \mathrm{ha}^{-1}\right)$ & Net return (Tk. ha $\left.{ }^{-1}\right)$ & BCR \\
\hline $\mathrm{T}_{1}$ (K Control) & 1276 & 89110 & 35543 & 53567 & 2.51 \\
\hline $\mathrm{T}_{2}\left(15 \mathrm{~kg} \mathrm{~K} \mathrm{ha}^{-1}\right)$ & 1487 & 104090 & 36313 & 67777 & 2.87 \\
\hline $\mathrm{T}_{3}\left(30 \mathrm{~kg} \mathrm{~K} \mathrm{ha}^{-1}\right)$ & 1528 & 106960 & 36593 & 70367 & 2.92 \\
\hline $\mathrm{T}_{4}\left(45 \mathrm{~kg} \mathrm{~K} \mathrm{ha}^{-1}\right)$ & 1645 & 115150 & 36893 & 78257 & 3.12 \\
\hline $\mathrm{T}_{5}\left(60 \mathrm{~kg} \mathrm{~K} \mathrm{ha}^{-1}\right)$ & 1684 & 117880 & 37223 & 80657 & 3.17 \\
\hline
\end{tabular}

Input prices: Urea $=$ Tk. $20 \mathrm{~kg}^{-1}$, T.S.P $=$ Tk. $22 \mathrm{~kg}^{-1}$, MoP=Tk. $16 \mathrm{~kg}^{-1}$, Gypsum= Tk. $8 \mathrm{~kg}^{-1}, \mathrm{Zinc}$ sulphate $=\mathrm{Tk} .140 \mathrm{~kg}{ }^{-1}, \mathrm{Boric}$ acid= Tk. $145 \mathrm{~kg}{ }^{-1}, \mathrm{Rovral}=$ Tk. $600100^{-\mathrm{g}}$, Karate = Tk. $450500^{-\mathrm{ml}}$, Lentil seed $=$ Tk. $80 \mathrm{~kg}^{-1}$, Plowing= Tk. $1400 \mathrm{ha}^{-1}$ (one pass), Wage rate $=$ Tk. $260 \mathrm{day}{ }^{-1}$

Output price: Lentil grain @ TK. $70 \mathrm{~kg}^{-1}$.

\section{Discussion}

Among the macro nutrients, $\mathrm{K}$ is a vital inorganic constituent, inherently involved in plant growth and development processes. However, management of $\mathrm{K}$ fertilizer is beneficial for improving the plant growth and yield contributing characters of crop [30]. Thus, Ali et al. [31] reported that application of $\mathrm{K}_{2} \mathrm{O} @ 150 \mathrm{~kg} \mathrm{ha}^{-1}$ produced significantly higher number of branches per plant of chickpea and second highest was produced by $125 \mathrm{~kg} \mathrm{~K}_{2} \mathrm{O}$ ha ${ }^{-1}$ which was statistically at par $100 \mathrm{~kg} \mathrm{~K}_{2} \mathrm{O} \mathrm{ha}{ }^{-1}$. In the present study, the number of primary branches per plant was increased about $9.4 \%, 28.1 \%, 28.6 \%$ and $30.8 \%$ by the application of $15,30,45$ and $60 \mathrm{~kg} \mathrm{~K} \mathrm{ha}{ }^{-1}$, respectively over $\mathrm{K}$ control. Potassium might be influenced on this increment of the branches. Potassium influences the physiological processes which are responsible for plant growth and development. Similar observation corroborated by Wang et al. [2]. Different rates of potassium contributed significantly $(\mathrm{P}<0.05)$ to improve the plant height of lentil. This study results showed that the highest plant height $(37.0 \mathrm{~cm})$ was obtained in the plot receiving of $60 \mathrm{~kg} \mathrm{~K} \mathrm{ha}^{-1}$ and the lowest $(30.7 \mathrm{~cm})$ was obtained from $\mathrm{K}$ control treatment. Hussain et al. [32] reported that application of different levels of $\mathrm{K}(0$, $30,60,90$, and $120 \mathrm{~kg}$ sulfate of potash (SOP) $\mathrm{ha}^{-1}$ ) in mungbean trial and found the highest plant height at $90 \mathrm{~kg}$ SOP $\mathrm{ha}^{-1}$ and the lowest at $0 \mathrm{~kg} \mathrm{~K} \mathrm{ha}^{-1}$. Sahay et al. [33] found highest plant height $(43.49 \mathrm{~cm})$ of lentil in the plot receiving of $90 \mathrm{~kg} \mathrm{~K}_{2} \mathrm{O} \mathrm{ha}{ }^{-1}$. Plant height is the significant part of vegetative phase that responsible to get higher biomass yield. However, $\mathrm{K}$ deficiency in soil is reduced the plant growth. Gerardeaux et al. [34] observed that the $\mathrm{K}$ deficiency in the vegetative phase of crops reduced the plant dry matter production, leaf area, and internode size, which leads to a reduction in plant growth. In the experiment, the maximum number of pods per plant (85.2) was found in the treatment receiving of $60 \mathrm{~kg} \mathrm{~K} \mathrm{ha}{ }^{-1}$. This result is in agreement with the findings of Zahan et al. (9). Ali et al. [31] reported on chickpea that application of $150 \mathrm{~kg} \mathrm{~K}_{2} \mathrm{O} \mathrm{ha}^{-1}$ produced significantly maximum number of pods plant ${ }^{-1}$ (61.9). Seed weight might be genetically controlled, the growing condition and nutrient (especially $\mathrm{K}$ ) management showed significant influence on its expression [3]. Highest seed weight in the study was obtained at $60 \mathrm{~kg} \mathrm{~K} \mathrm{ha}^{-1}$. Higher potash levels resulted appreciably in higher seed weight probably due to role of potash in translocation of photosynthates and its ability to develop bold seeds [31]. Sahay et al. [33] corroborated the similar result. Islam and Muttaleb [35] reported that the higher amount of K helps to transfer food material to develop grains.

Seed yield of lentil responded significantly to the application of potassium. Seed yield is the key reflection for any study involving to the seed production and commercial cultivation of a crop. The experimental results reveal that the 
highest seed yield was observed in the treatment receiving of $60 \mathrm{~kg} \mathrm{~K} \mathrm{ha}{ }^{-1}$. The study of Chanda et al. [36] concluded that the application of higher level of $120 \mathrm{~kg} \mathrm{~K} \mathrm{ha}^{-1}$ increased mungbean grain yield. Potassium might be regulated the biosynthesis, conversion, and allocation of metabolites that ultimately increases the yield. Many research works strongly supported the idea that $\mathrm{K}$ is directly or indirectly responsible for higher yield of crops [3]. Potassium involves increasing the utilization of carbohydrates, enhances the dry matter accumulation and ultimately increases the yields of crop [37]. The highest percent seed yield increase (31.9\%) over control was found by the application of $60 \mathrm{~kg} \mathrm{~K} \mathrm{ha}^{-1}$. Zahan et al. [9] reported that $34.2 \%$ lentil grain yield increase over control by the application of $42 \mathrm{~kg} \mathrm{~K}_{2} \mathrm{O} \mathrm{ha}{ }^{-1}$. In the present experiment, potassium influences the physiological processes which are responsible for plant growth, biomass production and development and eventually improved harvest index (38.7\%). Kirthisinghe [38] reported that the HI of lentil shown variability due to management practices and environmental condition. The variation of $\mathrm{HI}$ of lentil ranged from $1 \%$ to $60 \%$.

Nodulation results of the study showed that the number of nodules per plant was gradually increased from 32 days after sowing to 62 days after sowing, and then it was decreased. Number of nodules per plant in different dates was influenced significantly due to application of potassium. Maximum nodulation was happened in the improved dose of K. Ali and Srinivasarao [39] noted that improved K supply enhances biological nitrogen $(\mathrm{N})$ fixation. These findings were supported by Kurdali et al. [40]. Protein content in seed of lentil was observed highest $(29.4 \%)$ by the application of $60 \mathrm{~kg} \mathrm{~K} \mathrm{ha}{ }^{-1}$. Potassium might be involved to get improved protein. However, similar result was corroborated by Ali et al. [31] in chickpea who noted that the maximum protein content (23.87\%) in seed was recorded for $150 \mathrm{~kg} \mathrm{~K}_{2} \mathrm{O} \mathrm{ha}{ }^{-1}$. Wang et al. [2] studied on the correlation between phytohormones and $\mathrm{K}$; phytohormones interact with one another and other signaling molecules, which regulate biochemical processes and metabolism. Auxin-regulated genes regulate proteins that affect the transcriptional repressors of stress responses in plants [41].

Potassium is an essential macronutrient that plays significant role to uptake the $\mathrm{N}, \mathrm{P}, \mathrm{K}, \mathrm{S}, \mathrm{Zn}$, and $\mathrm{B}$ by lentil (seed and straw). In the present study, most of the nutrient showed highest uptake by lentil in application of $60 \mathrm{~kg} \mathrm{~K}^{-}$ 1. Our observation indicated that nutrient uptakes were significantly governed by the crops yield, performance of the yield attributes and nutrient concentration of crop. Potassium might be involed to enhance the crop growth with increase in utilization and translocation of other nutrient especially $\mathrm{N}$ to plant and synergy between $\mathrm{N}$ and $\mathrm{K}$ in soil system resulting in improvement of yield $[42,43]$. Hence, nutrient especially $\mathrm{K}$ uptake by lentil in $\mathrm{K}$-control plots can be a reliable measure of K-supplying capacity of soil [44, 45]. Different previous studies also reported that $\mathrm{K}$ applications have been influenced the uptake of N, P, K, S, Zn, and B by crops [46, 47].
There was a significant influence of $\mathrm{K}$ application on agronomic efficiency (AE) of $\mathrm{K}$ in lentil. Result of AE of $\mathrm{K}$ in some cases showed decreasing trend with increasing the $\mathrm{K}$ rate. Similar phenomenon noted by Islam et al. [6] in maize that lowest $\mathrm{AE}$ of $\mathrm{K}\left(12.9 \mathrm{~kg} \mathrm{~kg}^{-1}\right)$ was recorded for $\mathrm{K}$ dose $\left(160 \mathrm{~kg} \mathrm{ha}^{-1}\right)$. The physiological efficiency (PE) of the nutrient refers utilization capacity of nutrient by plant. The higher efficiency indicates more capacity of plant to increase yield with per unit nutrient uptake [25]. In this study, physiological efficiency of $\mathrm{K}$ in lentil was significantly influenced by different levels of $\mathrm{K}$. The PE of $\mathrm{K}$ in lentil decreased gradually with increase of $\mathrm{K}$ rates upto $45 \mathrm{~kg} \mathrm{ha}^{-1}$. The recovery efficiency of any nutrient refers to the increase in nutrient uptake by plants per unit of an applied nutrient. It depends on the growing environment and method of nutrient application. Apparent $\mathrm{K}$ recovery efficiency in lentil was significantly affected by different levels of $\mathrm{K}$ application. Other studies have also shown that crop K use efficiency depends on the rooting pattern of different crops and varieties, and their productivity, which depends also on the $\mathrm{K}$ status and $\mathrm{K}$ dynamics in soils [48, 49]. Potassium application in soil contributed positively to biomass production and increases the number of nodules per plant and both were influenced to the postharvest soil properties. In this trial, the $\mathrm{pH}$ of postharvest soils decreased slightly as compared with the initial value. Kumar and Yadev [50] and Mian and Eaqub [51] reported that continuous application of inorganic (NPK) fertilizer and incorporation of stover in soil resulted lower $\mathrm{pH}$ by 0.1 to 0.3 units. Different rates of $\mathrm{K}$ tended to maintain the initial fertility or increased slightly of soil organic matter, N, P, K, S, Zn and B. Organic matter might be increased the cation exchange capacity, which contributes to a high base saturation of the soil. Hence, the base saturation increases the relative amount of cations. The result of the experiment is supported by the researchersOgbodo [52]; Hinsinger, [53]. Our observation seemed that agronomic biofortification with $\mathrm{K}$ had a significant effect on the availability of nutrients in the soil. It has been reported that legume crops might be saved of about 23 to $30 \mathrm{~kg} \mathrm{~N}^{-1}$ for the succeeding crop [54]. The study has been denoted that rate of $60 \mathrm{~kg} \mathrm{~K} \mathrm{ha}{ }^{-1}$ economically viable due to obtain highest net return and benefit cost ratio. Similar results observed by Ali et al. [31] in chickpea.

\section{Conclusion}

From two years study it is clear that different rates of $\mathrm{K}$ significantly increased the seed yield of lentil. The application of potassium $60 \mathrm{~kg} \mathrm{ha}{ }^{-1}$ contributed significantly to have had more pod setting and seed weight, which ultimately enhanced the seed yield. The use of $60 \mathrm{~kg}$ $\mathrm{K} \mathrm{ha}^{-1}$ followed by $45 \mathrm{~kg} \mathrm{~K} \mathrm{ha}^{-1}$ had a significant effect to obtain the maximum number of nodules per plant and the highest protein content in seed. The total uptake of $\mathrm{N}, \mathrm{P}, \mathrm{K}$, $\mathrm{S}, \mathrm{Zn}$ and $\mathrm{B}$ was also highest in the plot receiving of $60 \mathrm{~kg}$ $\mathrm{K} \mathrm{ha}^{-1}$. The same dose was observed economically sound. Use of $60 \mathrm{~kg} \mathrm{~K} \mathrm{ha}^{-1}$ followed by $45 \mathrm{~kg} \mathrm{~K} \mathrm{ha}^{-1}$ showed 
encouraging effects on soil organic matter, total $\mathrm{N}$, available $\mathrm{P}, \mathrm{K}, \mathrm{Zn}$ and $\mathrm{B}$. Results of the current study

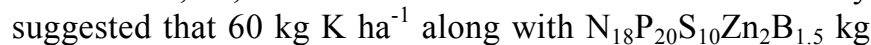
$\mathrm{ha}^{-1}$ is better for yield maximization of lentil and sustained the fertility of calcareous soils in Bangladesh. The present experiment also highlighted for the readjustment of $\mathrm{K}$ fertilizer dose by further study and to better understand the dynamics of $\mathrm{K}$ in lentil production.

\section{References}

[1] Wani, S. H.; Sah, S. K. (2014). Biotechnology and abiotic stress tolerance in rice. J. Rice Res., 2, 1000-1105.

[2] Wang, M.; Zheng, Q.; Shen, Q.; Guo, S. (2013). The critical role of potassium in plant stress response. Int. J. Mol. Sci., 14, 7370-7390.

[3] Hasanuzzaman, M., M. H. M. Borhannuddin Bhuyan,, Kamrun Nahar, Md. Shahadat Hossain, Jubayer Al Mahmud, Md. Shahadat Hossen, Abdul Awal Chowdhury Masud, Moumita and Masayuki Fujita. (2018). Potassium: a vital regulator of plant responses and tolerance to abiotic stresses. Agronomy, doi: 10.3390/agronomy8030031.

[4] Quddus, M. A., M. A. Hossain, H. M. Naser, B. Anwar, S. Aktar and M. Nazimuddin. (2018). Effect of zinc and boron application on productivity, quality and nutrient uptake of fieldpea (PisumsativumL.) grown in calcareous soils. Journal of Agricultural Science and Practice, 3 (6): 132-143.

[5] Dhuppar P, Biyan S, Chintapalli B, Rao S (2012). Lentil Crop Production in the Context of Climate Change: An Appraisal. Indian Research Journal of Extension Education, 2: 33-35.

[6] Islam, M. M., M. R. Karim, M. M. H. Oliver, T. A. Urmi, M. A. Hossain, and M. M. MoynulHaque. (2018). Impacts of Trace Element Addition on Lentil (Lens culinaris L.) Agronomy. Agronomy, 8 (7): 100; https://doi.org/10.3390/agronomy8070100

[7] Singh, G., Wade, L. J., Singh, B. B., Singh, R. K. and Singh, V. P. (2001). Nutrient management in semi- deep water (30-50 $\mathrm{cm})$ rice (Oryza sativa) and its effect on succeeding lentil (Lens culinaris) crop. Indian J. Agron., 46 (1): 12-16.

[8] Quddus, M. A., H. M. Naser, M. A. Hossain and M. Abul Hossain. (2014). Effect of zinc and boron on yield and yield contributing characters of lentil in low Ganges river floodplain soil at madaripur, Bangladesh. Bangladesh Journal of Agricultural Research, 39 (4): 591-603.

[9] Zahan, S. A., Alim, M. A., Hasan, M. M., U. K. Kabiraj and M. B. Hossain. (2009). Effect of potassium levels on the growth, yield and yield attributes of lentil. Int. J. Sustain. Crop Prod. 4 (6): 1-6.

[10] Regmi, A. P., J. K. Ladha, E. Pasquin, H. Pathak, P. R. Hobbs, L. L. Shrestha, D. B. Gharti, and E. Duveiller. (2002). The role of potassium in sustaining yields in a long-term ricewheat experiment in the Indo-Gangetic Plains of Nepal. Biology and Fertility of Soils 36: 240-247.

[11] Singh, M., V. P. Singh, and D. D. Reddy. (2002). Potassium balance and release kinetics under continuous rice-wheat cropping system in Vertisol. Field Crops Research 77: 81-91.
[12] Panaullah, G. M., J. Timsina, M. A., Saleque, M. Ishaque, A. B. M. B. U. Pathan, D. J. Connor, P. K. Saha, M. A. Quayyum, E. Humphreys, and C. A. Meisner. (2006). Nutrient uptake and apparent balances for rice-wheat sequences. III. Potassium. Journal of Plant Nutrition, 29: 173-187, DOI: 10.1080/01904160500416554.

[13] Srinivasarao, C., Masood Ali, A. N. Ganeshamurthy, and K. K. Singh. (2003). Potassium Requirements of Pulse Crops. Better Crops International, 17 (1): 8-11.

[14] Gupta, K., A. Dey and B. Gupta. (2013). Plant polyamines in abiotic stress responses. ActaPhysiologiaePlantarum, 35: 2015-2036.

[15] UNDP. (1988). Land resources appraisal of Bangladesh for agricultural development. Food and Agriculture Organization of the United Nations, Rome report 3, Vol. 1. Pp. 33-48.

[16] Black, C. A. (1965). Methods of Soil Analysis, Part I, Agron. Monograph. 9. ASA Madison, USA.

[17] Page, A. L., R. H. Miller, and D. R. Keeney (Eds.). (1982). Agronomy Series 9 ASA, SSSA. Methods of Soil Analysis (Part 2, 2nd ed., pp. 403-427). Am. Soc. Agron., Madison, USA.

[18] Bremner, J. M. and Mulvaney, C. S. (1982). Total nitrogen. In A. L. Page, R. H. Miller, D. R. Keeney (Eds.), Methods of Soil Analysis (Part 2, 2nd ed., pp. 599-622). Am. Soc. Agron., Madison, USA.

[19] Jackson, M. L. (1973). Soil Chemical Analysis (p. 498). Prentice Hall of India Private Limited, New Delhi.

[20] Gupta, P. K. (2004). Soil, Plant, Water and Fertilizer Analysis. Department of Agricultural Chemistry and Soil Science, Maharana Pratap University of Agriculture \& Technology, Rajasthan, India, Pp 168-170.

[21] Fox, R. L.; Olsen, R. A.; Rhoades, H. F. (1964). Evaluating the sulphur status of soil by plant and soil test. Soil Science Society of America Proc, 28, 243-246. https://doi.org/10.2136/sssaj1964.03615995002800020034x

[22] Lindsay, W. L. and Norvell, W. A. (1978). Development of DTPA soil test for zinc, iron, manganese and copper. Soil science Society of American. J., 42: 421-8.

[23] Piper, C. S. (1964). Soil and Plant Analysis. Adelaide University Press, Australia.

[24] Hiller, A., J. Plazin and D. D. Vanslyke. (1948). A study of conditions of Kjeldhal determination of nitrogen in proteins. $J$. Biol. Chem., 176 (3): 1401-1420.

[25] FRG (Fertilizer Recommendation Guide). (2012). Fertilizer Recommendation Guide, Published by Bangladesh Agricultural Research Council, Dhaka, Bangladesh.

[26] Paul, F.; Brentrup, F.; Bruulsema, T.; Garcia, F. Norton, R.; Zingore, S. (2014). Nutrient/fertilizer use efficiency: measurement, current situation and trends. IFA, IWMI, IPNI and IPI.

[27] Baligar, V. C., Fageria N. K. and He Z. L. (2001). Nutrient use efficiency in plants. Commun. Soil Sci. Plant Anal., 32 (7\&8), 921-950.

[28] Statistix 10. (1985). An Analytical Software, Po Box 12185, Tallahassee, FL 32317, Copy right (C) 1985-2013. 
[29] Tithi, S. M. and Barmon B. K. (2018). Comparative advantages of lentil (Lens culinaris) and mustard (Brassica nigra L.) production and their profitability in a selected district of Bangladesh. The Agriculturists, 16 (1): 21-33.

[30] Iqbal, A. and Hidayat, Z. (2016). Potassium management for improving growth and grain yield of maize (Zea mays L.) under moisture stress condition. Sci. Rep., 6, 34627.

[31] Ali, A., M. Ather Nadeem, A. Tanveer, M. Tahir and M. Hussain. (2007). Effect of different potash levels on the growth, yield and protein contents of chickpea (Cicer arietinum L.). Pak. J. Bot., 39 (2): 523-527.

[32] Hussain, F.; Malik, A. U.; Haji, M. A.; Malghani, A. L. (2011). Growth and yield response of two cultivars of mungbean (Vigna radiata L.) to different potassium levels. $J$. Anim. Plant Sci., 21, 622-625.

[33] Sahay, N., S. P. Singh and V. K. Sharma. (2013). Effect of cobalt and potassium application on growth, yield and nutrient uptake in lentil (Lens culinaris L.). Legume Res., 36 (3): 259262.

[34] Gerardeaux, E.; Jordan-Meille, L.; Constantin, J.; Pellerin, S.; Dingkuhn, M. (2010). Changes in plant morphology and dry matter partitioning caused by potassium deficiency in Gossypium hirsutum L. Environ. Exp. Bot., 67, 451-459.

[35] Islam, A. and A. Muttaleb. (2016). Effect of potassium fertilization on yield and potassium nutrition of Boro rice in a wetland ecosystem of Bangladesh. Arch. Agron. Soil Sci., 62: $1530-1540$.

[36] Chanda, N., S. S. Mondal, G. Arup and K. brahmachari. (2002). Effect of potassium and sulphur on mungbean in relation to growth, productivity and fertility build up of soil. Interacademiciam, 6 (3): 266- 271.

[37] Cheema, M. A., M. A. Wahid, A. Sattar, F. Rasul and M. F. Saleem. (2012). Influence of different levels of potassium on growth, yield and quality of canola (Brassica napus L.) cultivars. Pak. J. Agric. Sci. 49: 163-168.

[38] Kirthisinghe, 1P. 1986. Plant to plant variation in harvest index in lentil (Lens culinaris L.). DipAgrSc Dissertation. Lincoln College, University of Canterbury, New Zealand.

[39] Ali, M. and Ch. Srinivasarao. (2001). Proceeding of International Symposium on the Importance of Potassium in Nutrient Management for Sustainable Crop Production in India. Indian Institute of Pulses Research (PRII), Gurgaon. p. 261-278.

[40] Kurdali, F., Farid Al-Ain and Shamma M. A. (2002). Nodulation, dry matter production and $\mathrm{N}_{2}$ fixation by fababean and chickpea as affected by soil moisture potassium fertilizer. Journal of Plant Nutrition. 25 (2): 355-368.

[41] Shani, E.; Salehin, M.; Zhang, Y.; Sanchez, S. E.; Doherty, C.; Wang, R.; Mangado, C. C.; Song, L.; Tal, I.; Pisanty, O. (2017). Plant stress tolerance requires auxin-sensitive Aux/IAA transcriptional repressors. Curr. Biol., 27, 437-444.
[42] Guo, X. S., H. B. Zhu, W. J. Wang, S. Y. Ye, J. Wu, and L. S. Wu. (2004). Effect of Different Rates of Nitrogen and Potash on Yield and Quality of Cabbage. Plant Nutri. Fertil. Sci. 10 (2): 161-166 (in Chinese).

[43] Bruns, H. A., and M. W. Ebellhar. (2006). Nutrient Uptake of Maize Affected by Nitrogen and Potassium Fertility in a Humid Subtropical Environment. Commun. Soil. Sci. Plant Anal. 37: 275-293.

[44] Fergus, I. F.; Martin, A. E. (1974). Studies on potassium. IV. Interspecific differences in the uptake of non-exchangeable potassium. Soil Res., 12, 147-158.

[45] Memon, Y. M.; Fergus, I. F.; Hughes, J. D.; Page, D. W. (1988). Utilization of non-exchangeable soil potassium in relation to soil type, plant species and stage of growth. Soil Res., 26, 489-496.

[46] Kurhade, P. P., H. N. Sethi and R. S. Zadode. (2015). Effect of different levels of potassium on yield, quality, available nutrient and uptake of blackgram. Internat. J. agric. Sci., 11 (1): 175-178.

[47] Chaudhari, A. V., Mane S. S. and Chadar B. R. (2018). Effect of graded levels of potassium on growth, yield and quality of black gram. International Journal of Current Microbiology and Applied Sciences, Special Issue 6: 1607-1612.

[48] Darunsontaya, T.; Suddhiprakarn, A.; Kheoruenromne, I.; Prakongkep, N.; Gilkes, R. (2012). The forms and availability to plants of soil potassium as related to mineralogy for upland Oxisols and Ultisols from Thailand. Geoderma 2012, 170.

[49] Hussain, A.; Arshad, M.; Ahmad, Z.; Ahmad, H. T.; Afzal, M.; Ahmad, M. (2015). Potassium Fertilization and Maize Physiology Potassium Fertilization Influences Growth, Physiology and Nutrients Uptake of Maize (Zea mays L.). Cercet. Agron. Mold., XLVIII, 37-50.

[50] Kumar, A. and Yadev D. S. (1993). Effect of long-term fertilization on soil fertility and yield under rice-wheat cropping system. J. Indian Soc. Soil Sci. 41 (1): 178-180.

[51] Mian, M. J. A. and Eaqub M. (1981). Effect of intensive fertlization and manuring on some chemical properties of soil. Bangladesh J. Agril. Sci. 8 (2): 165-173.

[52] Ogbodo, E. N. (2011). Effect of crop residue on soil chemical properties and rice yield on an Ultisol at Abakaliki, Southeastern Nigeria. World J. Agric. Sci., 7, 13-18.

[53] Hinsinger, P. (1998). How do plant roots acquire mineral nutrients? Chemical processes involved in the rhizosphere. Adv. Agron., 64, 225-265.

[54] Ahlawat, I. P. S. and Srivastava, T. K. (1997). Fertility management in pulse based cropping systems. In Recent Advances in Pulses Research; Asthana, A. N., Masood, A., Eds.; Indian Society of Pulses Research and Development: Kanpur, India, pp. 509-523. 